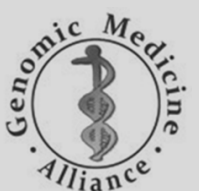

Genomic Medicine Alliance (GMA)

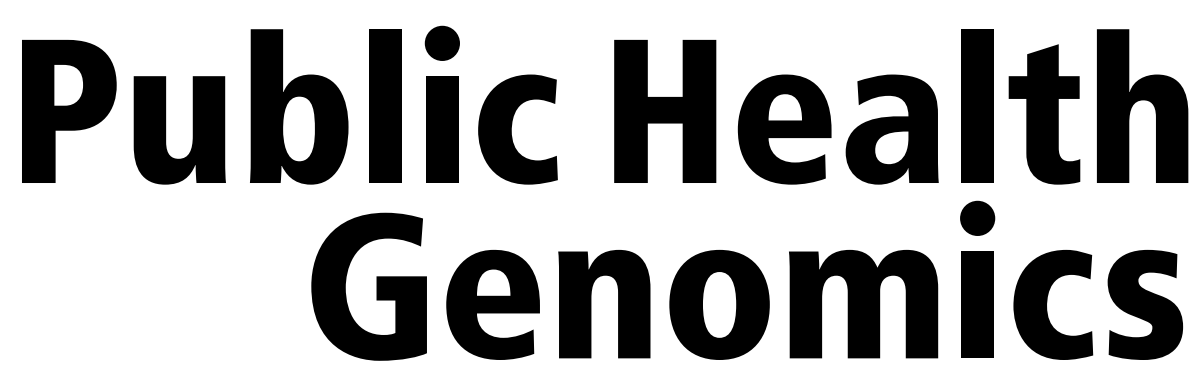

Founded 1998 as 'Community Genetics' by Leo ten Kate (1998-2008) Continued by B.M. Knoppers (2009-2011) and A.M. Brand as 'Public Health Genomics'

\title{
Editor-in-Chief
}

A.M. Brand, Maastricht, The Netherlands

\section{Scientific Editors}

M.J. Khoury, Atlanta, Ga., USA

S. Wallace, Leicester, UK

\section{Editorial Board}

R. Adany, Debrecen, Hungary

A. Aaro, Odense, Denmark

D. Avard, Montréal, Qué., Canada

I. Blancquaert, Montréal, Qué., Canada

J.-J. Cassiman, Leuven, Belgium

E.E. Castilla, Rio de Janeiro, Brazil

S. Grosse, Atlanta, Ga., USA

J. Harris, Oslo, Norway

A. Haslberger, Vienna, Austria

D. Ibarreta, Sevilla, Spain

M. Karmali, Toronto, Ont., Canada

H. Lehrach, Berlin, Germany

J. Little, Ottawa, Ont., Canada

N. Malats, Madrid, Spain

C. McBride, Bethesda, Md., USA

S.A. Morré, Amsterdam,

The Netherlands

P. O'Leary, Perth, W.A., Australia

F. Paccaud, Epalinges, Switzerland

B. Peterlin, Ljubljana, Slovenia

\section{Associate Editors}

E. Ambrosino, Maastricht, The Netherlands

N. Probst-Hensch, Basel, Switzerland
W. Ricciardi, Rome, Italy

C.N. Rotimi, Bethesda, Md., USA

K. Satyamoorthy, Manipal, India

P. Schröder-Bäck, Maastricht,

The Netherlands

D. Taruscio, Rome, Italy

H. van Kranen, Bilthoven,

The Netherlands

B. van Ommen, Zeist,

The Netherlands

H. van Oyen, Brussels, Belgium

$\mathrm{H}$. Vondeling, Odense, Denmark

J. Wilkinson, Stockton, UK

H. Yang, Shenzhen, China 
S. Karger

Medical and Scientific Publishers

Basel $\cdot$ Freiburg $\cdot$ Paris $\cdot$ London .

New York $\cdot$ Chennai $\cdot$ New Delhi $•$

Bangkok $\cdot$ Beijing $\cdot$ Shanghai $\cdot$ Tokyo $\cdot$

Kuala Lumpur $\cdot$ Singapore $\cdot$ Sydney

\section{Disclaimer}

The statements, opinions and data contained in this publication are solely those of the individual authors and contributors and not of the publisher and the editor(s). The appearance of advertisements in the journal is not a warranty, endorsement, or approval of the products or services advertised or of their effectiveness, quality or safety. The publisher and the editor(s) disclaim responsibility for any injury to persons or property resulting from any ideas, methods, instructions or products referred to in the content or advertisements.

Drug Dosage

The authors and the publisher have exerted every effort to ensure that drug selection and dosage set forth in this text are in accord with current recommendations and practice at the time of publication. However, in view of ongoing research, changes in government regulations, and the constant flow of information relating to drug therapy and drug reactions, the reader is urged to check the package insert for each drug for any change in indications and dosage and for added warnings and precautions. This is particularly important when the recommended agent is a new and/or infrequently employed drug.
All rights reserved.

No part of this publication may be translated into other languages, reproduced or utilized in any form or by any means, electronic or mechanical, including photocopying, recording, microcopying, or by any information storage and retrieval system, without permission in writing from the publisher or, in the case of photocopying, direct payment of a specified fee to the Copyright Clearance Center (see 'General Information')

(c) Copyright 2014 by S. Karger AG,

CH-4009 Basel (Switzerland)

Printed on acid-free and non-aging paper (ISO 9706)

\section{KARGER}




\section{Public Health Genomics}

No. 1

Original Papers

1 Racial Differences in Attitudes toward Personalized Medicine Diaz, V.A.; Mainous III, A.G.; Gavin, J.K. (Charleston, S.C.); Wilson, D. (Orangeburg, S.C.)

7 Characteristics of Genetics-Related News Content in Black Weekly Newspapers

Caburnay, C.A.; Babb, P.; Kaphingst, K.A.; Roberts, J.; Rath, S. (St. Louis, Mo.)

16 After the Introduction into the National Newborn Screening Program: Who Is Receiving Genetic Counseling for Hemoglobinopathies in The Netherlands?

Kaufmann, J.O. (Leiden); Krapels, I.P.C. (Maastricht); Van Brussel, B.T.J. (Leiden); Zekveld-Vroon, R.C. (Rotterdam); Oosterwijk, J.C. (Groningen); van Erp, F. (Nijmegen); van Echtelt, J. (Utrecht); Zwijnenburg, P.J.G. (Amsterdam); Petrij, F. (Rotterdam); Bakker, E.; Giordano, P.C. (Leiden)

23 Perceptions of African-American Health Professionals and Community Members on the Participation of Children and Pregnant Women in Genetic Research Ngui, E.M. (Milwaukee, Wis.); Warner, T.D. (Albuquerque, N.Mex.); Roberts, L.W. (Stanford, Calif.)

33 Knowledge, Group-Based Medical Mistrust, Future Expectations, and Perceived Disadvantages of Medical Genetic Testing: Perspectives of Black African Immigrants/ Refugees

Buseh, A.; Kelber, S.; Millon-Underwood, S.; Stevens, P.; Townsend, L. (Milwaukee, Wis.)

43 Patients' Understanding of How Genotype Variation Affects Benefits of Tamoxifen Therapy for Breast Cancer Brewer, N.T.; DeFrank, J.T.; Chiu, W.K.; Ibrahim, J.G. (Chapel Hill, N.C.); Walko, C.M. (Tampa, Fla.); Rubin, P. (Greensboro, N.C.); Olajide, O.A.; Moore, S.G. (Raleigh, N.C.); Raab, R.E. (Greenville, S.C.); Carrizosa, D.R. (Charlotte, N.C.); Corso, S.W. (Spartenburg, S.C.); Schwartz, G. (Concord, N.C.); Peppercorn, J.M. (Durham, N.C.); McLeod, H.L. (Tampa, Fla.); Carey, L.A. (Chapel Hill, N.C.); Irvin Jr., W.J. (Chapel Hill, N.C./Richmond, Va.)

48 Interest and Informational Preferences Regarding Genomic Testing for Modest Increases in Colorectal Cancer Risk Anderson, A.E. (Salt Lake City, Utah); Flores, K.G. (Albuquerque, N.Mex.); Boonyasiriwat, W. (Salt Lake City, Utah/Bangkok); Gammon, A.; Kohlmann, W. (Salt Lake City, Utah); Birmingham, W.C. (Provo, Utah); Schwartz, M.D. (Washington D.C.); Samadder, J.; Boucher, K. (Salt Lake City, Utah); Kinney, A.Y. (Salt Lake City, Utah/Albuquerque, N.Mex.)
No. 2

Policy Statement

115 European Recommendations for Primary Prevention of Congenital Anomalies: A Joined Effort of EUROCAT and EUROPLAN Projects to Facilitate Inclusion of This Topic in the National Rare Disease Plans

Taruscio, D. (Rome); Arriola, L. (San Sebastián); Baldi, F. (Rome); Barisic, I. (Zagreb); Bermejo-Sánchez, E. (Madrid); Bianchi, F. (Pisa); Calzolari, E. (Ferrara); Carbone, P. (Rome); Curran, R. (Ulster); Garne, E. (Kolding); Gatt, M. (Guardamangia); Latos-Bieleńska, A. (Poznan); Khoshnood, B. (Paris); Irgens, L. (Bergen); Mantovani, A. (Rome); Martínez-Frías, M.L. (Madrid); Neville, A. (Ferrara); Rißmann, A. (Magdeburg); Ruggeri, S. (Rome); Wellesley, D. (Southampton); Dolk, H. (Ulster)

Original Papers

76 Impact of Academic Affiliation and Training on Knowledge of Hereditary Colorectal Cancer

Chan, V.; Blazey, W.; Tegay, D.; Harper, B.; Koehler, S.; Laurent, B.

(Old Westbury, N.Y.); Lipka, S. (East Meadow, N.Y.); Cohn, J.; Jung, M.-K.; Krishnamachari, B. (Old Westbury, N.Y.)

84 Community Engagement in US Biobanking: Multiplicity of Meaning and Method

Haldeman, K.M.; Cadigan, R.J.; Davis, A. (Chapel Hill, N.C.); Goldenberg, A. (Cleveland, Ohio); Henderson, G.E.; Lassiter, D.; Reavely, E. (Chapel Hill, N.C.)

95 Impact of Delivery Models on Understanding Genomic Risk for Type 2 Diabetes

Haga, S.B.; Barry, W.T.; Mills, R.; Svetkey, L.; Suchindran, S.; Willard, H.F.; Ginsburg, G.S. (Durham, N.C.)

105 Parents' Preferences for Return of Results in Pediatric Genomic Research

Ziniel, S.I.; Savage, S.K.; Huntington, N. (Boston, Mass.); Amatruda, J. (Farmington, Conn.); Green, R.C.; Weitzman, E.R.; Taylor, P.; Holm, I.A. (Boston, Mass.)

Short Communications

61 Latin American Collaborative Study of Congenital Malformations (ECLAMC): A Model for Health Collaborative Studies

Poletta, F.A. (Buenos Aires/Rio de Janeiro); Gili, J.A. (Buenos Aires); Castilla, E.E. (Buenos Aires/Rio de Janeiro)

68 Young Smokers' Interpretations of the Estimated Lung Cancer Risk Associated with a Common Genetic Variant of Low Penetrance

Sanderson, S.C. (New York, N.Y.); McBride, C.M. (Bethesda, Md.); O’Neill, S.C (Washington, D.C.); Docherty, S. (Durham, N.C.); Shepperd, J.

(Gainesville, Fla.); Lipkus, I.M. (Durham, N.C.)

\section{KARGER}

E-Mail karger@karger.com www.karger.com
(C) 2014 S. Karger AG, Basel

Access to full text and tables of contents, including tentative ones for forthcoming issues: www.karger.com/phg_issues 
No. 3

Editorial

125 Public Health Genomics Joins Forces with the Genomic Medicine Alliance

Patrinos, G.P. (Patras); Brand, A. (Maastricht)

Original Papers

127 Understanding Consumer Evaluations of Personalised Nutrition Services in Terms of the Privacy Calculus: A Qualitative Study

Berezowska, A.; Fischer, A.R.H.; Ronteltap, A. (Wageningen); Kuznesof, S (Newcastle upon Tyne); Macready, A.; Fallaize, R. (Reading); van Trijp, H.C.M. (Wageningen)

141 Attitudes of Parents of Children with Serious Health Conditions regarding Residual Bloodspot Use

Nagaraj, C.B. (Salt Lake City, Utah/Cincinnati, Ohio); Rothwell, E.; Hart, K. Latimer, S.; Schiffman, J.D.; Botkin, J.R. (Salt Lake City, Utah)

149 Protecting Personal Data in Epidemiological Research: DataSHIELD and UK Law

Wallace, S.E. (Leicester); Gaye, A. (Bristol); Shoush, O. (Leicester); Burton, P.R. (Bristol)

158 Playing a Part in Research? University Students' Attitudes to Direct-To-Consumer Genomics

Vayena, E.; Ineichen, C. (Zurich); Stoupka, E. (Milano); Hafen, E. (Zurich)

169 Discordance between Self-Report and Genetic Confirmation of Sickle Cell Disease Status in African-American Adults

Bean, C.J.; Hooper, W.C.; Ellingsen, D. (Atlanta, Ga.); DeBaun, M.R. (Nashville, Tenn.); Sonderman, J. (Rockville, Md.); Blot, W.J. (Nashville, Tenn./Rockville, Md.)

173 Intentions to Donate to a Biobank in a National Sample of African Americans

McDonald, J.A. (New York, N.Y.); Vadaparampil, S. (Tampa, Fla.); Bowen, D. (Boston, Mass.); Magwood, G.; Obeid, J.S.; Jefferson, M.; Drake, R.; Gebregziabher, M.; Hughes Halbert, C. (Charleston, S.C.)

No. 4

Review

190 Medical Genetic Counseling for Breast Cancer in Primary Care: A Synthesis of Major Determinants of Physicians' Practices in Primary Care Settings

Jbilou, J. (Moncton, N.B.); Halilem, N.; Blouin-Bougie, J.; Amara, N.;

Landry, R.; Simard, J. (Quebec, Qué.)

Original Papers

183 Increasing Rates of Prenatal Testing among Jewish and Arab Women in Israel over One Decade

Romano-Zelekha, O. (Ramat Gan); Ostrovsky, J. (Tel Aviv); Shohat, T. (Ramat Gan/Tel Aviv)

209 Personalized Medicine, Availability, and Group Disparity: An Inquiry into How Physicians Perceive and Rate the Elements and Barriers of Personalized Medicine Petersen, K.E.; Prows, C.A.; Martin, L.J.; Maglo, K.N. (Cincinnati, Ohio)

228 Anticipated Motivation for Genetic Testing among Smokers, Nonsmokers, and Former Smokers: An Exploratory Qualitative Study of Decision Making

Giordimaina, A.M. (Ann Arbor, Mich.); Sheldon, J.P. (Dearborn, Mich.); Petty, E.M. (Madison, Wis.)
Short Communication

221 Developing Clinical Cancer Genetics Services in Resource Limited Countries: The Case of Retinoblastoma in Kenya He, L.Q. (Toronto, Ont.); Njambi, L.; Nyamori, J.M.; Nyenze, E.M.; Kimani, K. (Nairobi); Matende, I. (Mombasa); Rono, H. (Kitale); Njom, V. (Mombasa); Bett, J. (Eldoret); Mukuria, M.; Gachago, M. (Nairobi); Roberts, H. (Kwale); Dimaras, H. (Toronto, Ont.)

No. 5-6

Editorial

245 Public Health Pharmacogenomics

Patrinos, G.P. (Patras)

Public Health Pharmacogenomics

248 Clinical Application of Pharmacogenomics: The Example of HLA-Based Drug-Induced Toxicity

Lee, M.T.M. (Yokohama/Taipei); Mahasirimongkol, S. (Nonthaburi); Zhang, Y. (Yokohama); Suwankesawong, W. (Nonthaburi); Chaikledkaew, U. (Bangkok); Pavlidis, C.; Patrinos, G.P. (Patras); Chantratita, W. (Bangkok/Taipei)

256 Economic Evaluation of Pharmacogenomics: A Value-Based Approach to Pragmatic Decision Making in the Face of Complexity

Snyder, S.R. (Danville, Pa.); Mitropoulou, C. (Rotterdam); Patrinos, G.P. (Patras); Williams, M.S. (Danville, Pa.)

265 DruGeVar: An Online Resource Triangulating Drugs with Genes and Genomic Biomarkers for Clinical Pharmacogenomics

Dalabira, E; Viennas, E. Daki, E · Komianou, A · Bartsakoulia, M. Poulas, K.; Katsila, T.; Tzimas, G.; Patrinos, G.P. (Patras)

272 Assessment of the Pharmacogenomics Educational Environment in Southeast Europe

Pisanu, C. (Cagliari); Tsermpini, E.-E.; Mavroidi, E.; Katsila, T.; Patrinos, G.P (Patras); Squassina, A. (Cagliari)

280 Stakeholder Analysis in Pharmacogenomics and Genomic Medicine in Greece

Mitropoulou, C. (Rotterdam); Mai, Y. (Patras); van Schaik, R.H. (Rotterdam); Vozikis, A. (Piraeus); Patrinos, G.P. (Patras)

287 An Index of Barriers for the Implementation of Personalised Medicine and Pharmacogenomics in Europe

Horgan, D. (Brussels); Jansen, M.; Leyens, L.; Lal, J.A. (Maastricht); Sudbrak, R. (Berlin); Hackenitz, E. (The Hague); Bußhoff, U.; Ballensiefen, W. (Bonn); Brand, A. (Maastricht)

299 Personal Genomics in Greece: An Overview of Available Direct-to-Consumer Genomic Services and the Relevant Legal Framework

Kechagia, S. (Geneva); Mai, Y. (Patras); Vidalis, T. (Rethymno); Patrinos, G.P. (Patras); Vayena, E. (Zurich)

306 Cost-Effectiveness of IL28B Genotype-Guided Protease Inhibitor Triple Therapy versus Standard of Care Treatment in Patients with Hepatitis C Genotypes 2 or 3 Infection Bock, J.A.; Fairley, K.J.; Smith, R.E.; Maeng, D.D.; Pitcavage, J.M.; Inverso, N.A.; Williams, M.S. (Danville, Pa.)

320 Author Index/Subject Index 